\title{
Constitutive nuclear factor- $\kappa B$ activity in human upper airway tissues and nasal epithelial cells
}

\author{
I. Ramis*, G. Bioque*, J. Lorente**, P. Jares*, P. Quesada**, J. Roselló-Catafau*, \\ E. Gelpí*, O. Bulbena*
}

\begin{abstract}
Constitutive nuclear factor- $\kappa B$ activity in human upper airway tissues and nasal epithelial cells. I. Ramis, G. Bioque, J. Lorente, P. Jares, P. Quesada, J. Roselló-Catafau, E. Gelpí, O. Bulbena. (C) ERS Journals Ltd 2000.

ABSTRACT: Respiratory epithelial cells are actively involved in the host defence and inflammatory reactions of the airways. Nuclear factor $-\kappa B(N F-\kappa B)$ is a transcription factor that plays a pivotal role in many cellular responses to environmental changes. The inducible nitric oxide synthase (iNOS) isoform has been implicated in airway inflammation as well as in normal airway function. In this study, the hypothesis that $N F-\kappa B$ may be associated with iNOS expression in airway epithelium, not only in inflammatory processes but also under physiological conditions was examined.

$\mathrm{NF}-\kappa \mathrm{B}$ deoxyribonucleic acid-binding activity was assayed by means of electrophoretic mobility shift assay (EMSA) and iNOS expression examined using immunohistochemical techniques in healthy nasal mucosa and chronically inflamed nasal polyps. Further NF- $\kappa$ B activity was assayed; by means of EMSA, in nasal epithelial cells isolated from both tissues.

$N F-\kappa B$ was activated in nasal polyps, but also to the same extent in healthy nasal mucosa. Uniform iNOS expression was localized within the airway epithelium in both inflamed and noninflamed tissues. Along with iNOS expression, concomitant NF- $\kappa$ B activation was found in nasal epithelial cells obtained from both tissues and no differences were observed when nasal mucosa and nasal polyp were compared.

These results suggest that constitutive nuclear factor- $\kappa \mathbf{B}$ and concurrent inducible nitric oxide synthase expression in epithelial cells may play a physiological role in airway function.
\end{abstract}

Eur Respir J 2000; 15: 582-589.

*Dept of Medical Bioanalysis, Instituto de Investigaciones Biomédicas de Barcelona, CSIC-IDIBAPS, and **Dept of Ear, nose and throat, Hospital Valle de Hebrón, Barcelona, Spain.

Correspondence: I. Ramis, Dept of Medical Bioanalysis, Instituto de Investigaciones Biomédicas de Barcelona CSIC, c/ Rosellón 161, 08036-Barcelona, Spain. Fax: 34933638301

Keywords: Epithelial cells

human airways

inducible nitric oxide synthase

nuclear factor- $\kappa \mathrm{B}$

Received: July 111999

Accepted after revision December 311999

Supported by grants 96/2188 E and 98/ 1367 from the Fondo de Investigación Sanitaria of Spain and BMH4-CT95-0639 from the Commision of the European Communities.

The nasal epithelium represents the respiratory system's first line of defence against inhaled stimuli such as viruses, bacteria, inflammatory stimuli and environmental pollutants. Airway epithelial cells are able to respond to such frequent environmental stresses by secreting pro-inflammatory mediators [1]. Nuclear factor- $\kappa \mathrm{B}(\mathrm{NF}-\kappa \mathrm{B})$ plays a pivotal role in cellular responses to environmental changes by regulating the expression of specific sets of inducible genes involved in the immune response, and acute phase and inflammatory processes [2]. In resting cells, $\mathrm{NF}-\kappa \mathrm{B}$ resides in the cytoplasm as an inactive form complexed to a member of the family of inhibitory proteins

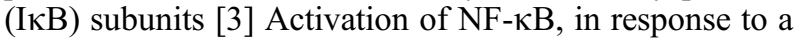
variety of extracellular signals, leads to the release of the $\mathrm{I} \kappa \mathrm{B}$ subunit from the cytoplasmic complex, which is translocated into the nucleus where it activates its target genes upon binding to various $\mathrm{\kappa B}$ motifs [4].

Active NF- $\kappa \mathrm{B}$ is composed of two members of the Rel family of proteins. The best characterized form of this factor is the p50/p65 heterodimer; however, other members of the Rel family of proteins, including c-Rel, Rel B, v-Rel and P52, can form various hetero- and homodimers in a wide variety of cell types [5]. Previous studies have shown that $N F-\kappa B$ regulates the transcription of the inducible nitric oxide synthase (iNOS) gene in murine macrophages $[6,7], 3$ T3 fibroblasts [8] and human vascular smooth muscle cells [9]. Increasing evidence, based upon higher than normal levels of nitric oxide in the exhaled air of asthmatic patients $[10,11]$ and prominent immunostaining for iNOS in asthmatic airway epithelium [12], suggests that the iNOS isoform may play a role in acute and chronic inflammatory airway diseases. In the upper airways, increased iNOS activity [13] and expression [14] have been shown in chronically inflamed nasal polyp tissues. Despite the reported iNOS upregulation under inflammatory conditions, exciting new findings have demonstrated that iNOS is continuously expressed in normal airway epithelium [15], implying a homeostatic role for this isoform not previously considered. The mechanisms of the continuous and induced iNOS expression in epithelial cells are unknown. However, NF- $\kappa$ B activity in normal and inflammatory airway epithelium has not been fully examined.

It was hypothesized that NF- $\mathrm{NB}$ may be associated with airway epithelium iNOS expression, not only in airway inflammatory processes but also under physiological conditions. In the present study, this question was addressed by examining NF- $\kappa \mathrm{B}$ activity, by means of electrophoretic mobility shift assay (EMSA), and iNOS expression, using immunohistochemical techniques, in healthy nasal mucosa and nasal polyps. In addition, NF- $\mathrm{BB}$ activity was assayed in nasal epithelial cells obtained from both tissues. 


\section{Material and methods}

\section{Subjects}

Nasal polyps were obtained from 19 patients (12 males and 7 females; mean age $49 \pm 4$ yrs) who underwent polypectomy because of nasal obstruction. Three of the patients had allergic rhinitis, eight bronchial asthma and eight no history of airway disease. Twelve patients were receiving topical nasal steroids, two of whom also received inhaled steroids, and five of whom also took systemic corticosteroids when symptoms required. Nasal mucosal tissues were obtained from 13 patients (nine males and four females; mean age $33 \pm 11$ yrs who required corrective surgical treatment for nasal obstruction. These patients had no clinical history of inflammatory airway disease and were not receiving any medication 1 month prior to surgery.

\section{Tissue processing}

Tissues were processed immediately following resection. For the NF- $\mathrm{kB}$ deoxyribonucleic acid (DNA)-binding activity assay, pieces of tissue were immediately frozen in liquid nitrogen and stored at $-80^{\circ} \mathrm{C}$. For the immunohistochemical techniques, the tissues were cut into several pieces of $\sim 5-\mathrm{mm}$ thick and fixed in periodate-lysine-paraformaldehyde, frozen in Tissue-Tek $\mathbb{R}$ ornithine carbamoyltransferase (OCT) medium(Miles Laboratories, Elkhart, IN, USA) and processed as previously described [13]. For epithelial cell culture, intact tissues were placed in Dulbecco's modified Eagle's medium (DMEM)/Ham's F12 medium 1:1 (Life Technologies, Merelbeke, Belgium) and immediately transported on ice to the laboratory for processing.

\section{Epithelial cell culture}

Nasal epithelial cells were cultured by means of the explant cell culture technique previously described [16]. Epithelial sections (one section per dish) were explanted into 35-mm diameter Falcon $\mathbb{R}$ Primaria ${ }^{\mathrm{TM}}$ plastic culture dishes (Becton Dickinson, Oxford, UK) containing $1 \mathrm{~mL}$ DMEM/Ham's F12 $1: 1$ and $100 \mathrm{U} \cdot \mathrm{mL}^{-1}$ penicillin, 100 $\mu \mathrm{g} \cdot \mathrm{mL}^{-1}$ streptomycin, $0.25 \mu \mathrm{g} \cdot \mathrm{mL}^{-1}$ amphotericin $\mathrm{B}$ and $2 \%$ Ultroser $\mathrm{G}$ (Life Technologies). The explants were incubated in a $5 \%$ carbon dioxide/air atmosphere at $37^{\circ} \mathrm{C}$. All explants were observed for cell outgrowth after 3 days and the medium was replaced every $48 \mathrm{~h}$ until the cells had grown to confluence, which normally took 3 weeks. The purity of the cultures and the identity of the cells were confirmed by light microscopy and immunofluorescence staining using an anti-pan cytokeratin monoclonal antibody (Sigma, St. Louis, MO, USA).

\section{Nuclear extract preparation}

Nuclear proteins were extracted from tissues according to a previously described method [17]. Nuclear proteins were extracted from epithelial cells as previously described [18], with a few modifications. The cell layers were washed twice with ice-cold Dulbecco's phosphate-buffered saline (PBS) without calcium and magnesium (Gibco Laboratories, Paisley, UK) at $\mathrm{pH} 7.4$, scraped off the dishes and sedimented by centrifugation $30 \mathrm{~s}$ (at 16,000 $\times g$ ). The cell pellets were resuspended in $200 \mu \mathrm{L}$ of ice cold hypotonic lysis buffer containing $10 \mathrm{mM} \mathrm{N}$-2-hy- droxyethylpiperazine- $N$-2-ethanesulphoric acid (HEPES) (pH 7.9), $10 \mathrm{mM} \mathrm{KCl}, 1.5 \mathrm{mM} \mathrm{MgCl}_{2}, 1 \mathrm{mM}$ dithiothreitol (DTT), $0.5 \mathrm{mM}$ phenylmethylsulphonyl fluoride (PMSF), $2 \mu \mathrm{g} \cdot \mathrm{mL}^{-1}$ leupeptin and $5 \mu \mathrm{g} \cdot \mathrm{mL}^{-1}$ aprotinin. Cells were allowed to swell on ice for $15 \mathrm{~min}$ and then Nonidet P-40 (Boehringer Mannheim, Mannheim, Germany) was added to a final concentration of $0.6 \%$. The tubes were gently agitated on a vortext mixer for $10 \mathrm{~s}$ to disrupt plasma membranes, and nuclei were sedimented by centrifugation for $30 \mathrm{~s}$ at $16,000 \times g$ at $4^{\circ} \mathrm{C}$. The nuclear pellet was resuspended in $25 \mu \mathrm{L}$ of high-salt nuclear lysis buffer containing $20 \mathrm{mM}$ HEPES (pH 7.9), 0.46 M NaCI, $1 \mathrm{mM}$ ethylenediamine tetraacetic acid (EDTA), $1 \mathrm{mM}$ ethyleneglycol-bis-( $\beta$-aminoethylether)- $N, N, N^{\prime}, N^{\prime}$-tetracetic acid, $1 \mathrm{mM}$ DTT, $0.5 \mathrm{mM}$ PMSF, $2 \mu \mathrm{g} \cdot \mathrm{mL}^{-1}$ leupeptin and 5 $\mu \mathrm{g} \cdot \mathrm{mL}^{-1}$ aprotinin and incubated for $15 \mathrm{~min}$ at $4{ }^{\circ} \mathrm{C}$ with gentle orbital shaking. Nuclear proteins were extracted by centrifugation for $30 \mathrm{~min}$ at $16,000 \times g$ at $4{ }^{\circ} \mathrm{C}$. Aliquots of the supernatant were immediately frozen and stored at $-80^{\circ} \mathrm{C}$. All steps were carried out at $4^{\circ} \mathrm{C}$. Protein concentration was determined according to the method of BRADFORD [19].

\section{Nuclear factor $-\kappa B$ electrophoretic mobility shift assay}

The binding reactions were performed on ice in a volume of $15-20 \mu \mathrm{L}$ containing $10 \mathrm{mM}$ tris-hydroxymethylamino methane $\mathrm{HCl}(\mathrm{pH} 8.0), 25 \mathrm{mM} \mathrm{KCl}, 0.5 \mathrm{mM}$ DTT, $0.1 \mathrm{mM}$ EDTA, $5 \%$ glycerol, $5 \mathrm{mg} \cdot \mathrm{mL}^{-1}$ bovine serum albumin, $50 \mu \mathrm{g} \cdot \mathrm{mL}^{-1}$ poly (deoxyinosine-deoxycytidine) (Pharmacia Biotech, Uppsala, Sweden,), $100 \mu \mathrm{g} \cdot \mathrm{mL}^{-1}$ transfer ribonucleic acid (Sigma) and $4 \mu \mathrm{g}$ of nuclear protein extract. A preincubation of $10 \mathrm{~min}$ was allowed prior to adding 20,000 counts per minute ${ }^{32} \mathrm{p}-5^{\prime}$-end-labelled doublestranded oligonucleotide (5'-AGTTGAGGGGACTTTCCCAGGC-3') containing the consensus NF- $\kappa$ B site (Promega, Madison, WI, USA), and the incubation continued for a further $15 \mathrm{~min}$ period. The $\mathrm{NF}-\kappa \mathrm{B}$ complexes were separated on a $4 \%$ nondenaturing polyacrylamide gel (previously electrophoresed for $45 \mathrm{~min}$ at $5 \mathrm{~V} \cdot \mathrm{cm}^{-1}$ ) in $0.3 \times$ tris-borate-ethylenediamine tetraacetic acid (TBE) buffer for $1.5 \mathrm{~h}$ at $10 \mathrm{~V} \cdot \mathrm{cm}^{-1}$. The gel was transferred on to DE 81 cellulose paper (Whatman, Maidstone, UK), dried under vacuum at $80^{\circ} \mathrm{C}$ and exposed overnight at $-70^{\circ} \mathrm{C}$ to an $\mathrm{X}$ OMAT AR film (Kodak, Rochester, NY, USA) using an intensifying screen. Autoradiographic bands were quantified by densitometric scanning. The specificity of the gel shift complexes was determined by preincubation with a 70 -fold excess of unlabelled NF- $\kappa \mathrm{B}$ probe or the nonspecific unlabelled activator protein (AP-1) oligonucleotide (Promega). In order to identify the subunits that constitute the $\mathrm{NF}-\kappa \mathrm{B}$ complex present in tissue and epithelial cell samples, specific antisera recognizing the P50, P65 and c-Rel subunits (generously provided by N. Rice) were preincubated with the nuclear extracts for $10 \mathrm{~min}$ prior to the addition of the labelled probe.

\section{Inducible nitric oxide synthase immunostaining}

Immunohistochemical staining for iNOS was performed using the immunoperoxidase technique. The thawed slides were rinsed in PBS ( $\mathrm{pH} 7.4$; Gibco) to remove OCT and incubated with $0.55 \% \mathrm{H}_{2} \mathrm{O}_{2}$ in methanol in order to inactivate endogenous peroxidase. Sections were rinsed twice 
for 5 min with PBS and incubated with human $\mathrm{AB}$ blood type sera (1:20 in PBS) for 20 min to block nonspecific reactions, then slides were incubated overnight at $4^{\circ} \mathrm{C}$ with a mouse monoclonal antibody raised against mouse macrophage iNOS, which recognizes human iNOS (Transduction Laboratories, Lexington, KY, USA) at $5 \mu \mathrm{g} \cdot \mathrm{mL}^{-1}$ in PBS. Mouse immunoglobulin (Ig)G2a myeloma proteins (Sigma) were used as negative control for the primary antibody. After two more 5-min washes, the slides were incubated at room temperature with biotinylated rabbit antimouse Igs (Dako, Glostrup, Denmark) diluted 1:400 in PBS containing human AB sera (1:200) for 30 min. After washing with PBS, the sections were incubated with a streptavidin/biotinylated horseradish peroxidase complex kit (Dako) for $40 \mathrm{~min}$ according to the manufacturer's instructions. After washing, the sections were exposed to $0.05 \%$ 3,3'-diaminobenzidine (Sigma) and finally counterstained with Harris haematoxylin solution $\left(17 \mathrm{mg} \cdot \mathrm{mL}^{-1}\right.$; Sigma), dehydrated and DPX- (BDH, Poole, UK) mounted. For the evaluation of immu-nohistochemical iNOS protein signals, all tissue samples were coded and sections counted in a blinded fashion. For each tissue, a total of 20 fields were examined at a final magnification of $\times 400$ and the number of positively-stained cells was recorded.

\section{Statistical analysis}

The NF-кB-binding band densities in tissues and epithelial cells are presented as mean \pm SEM. The unpaired t-test was used for comparisons between groups. A p-value of $<0.05$ was considered significant.

\section{Results}

Nuclear factor $-\kappa B$ activity in nasal mucosa and nasal polyp tissue

NF- $\kappa \mathrm{B}$-binding activity was measured by EMSA in nuclear extracts from healthy nasal mucosa and chronically inflamed nasal polyps. As shown in figure 1, both types of tissue contained one retarded band, which was completely absent in the presence of an excess of the unlabelled $\mathrm{NF}-\kappa \mathrm{B}$ probe, but not in the presence of an unrelated oligonucleotide (AP-I consensus site), confirming that the nuclear proteins bind specifically to the NF- $\kappa \mathrm{B}$ consensus sequence in the EMSA. These data indicate the presence of constitutive NF- $\mathrm{B}$ activity in human upper airway tissue, either normal or inflamed. When the intensity of the NF- $\kappa \mathrm{B}-$ retarded bands was analysed by means of densitometry no difference was found between normal or inflamed tissues (fig. 1b). The NF- $\kappa$ B activity in polyps from patients who were receiving steroid therapy did not statistically differ from those who were not receiving treatment before polypectomy. Analysis of the subunit composition by means of supershift assay showed that specific antisera directed against the p50 subunit completely supershifted the NF- $\kappa \mathrm{B}$ complex in both tissues (fig. 2), and the p65 antisera caused a partial further retardation of the specific NF- $\kappa$ B-retarded band. Anti c-Rel and nonimmune rabbit serum did not result in any supershift. These data show that both tissues assayed, healthy and inflamed, have the same pattern of subunit composition and reveal the predominance of the p50 subunit, as well as the presence of $\mathrm{p} 65$, in the activated NF- $\mathrm{KB}$ complexes detected in human upper airways.
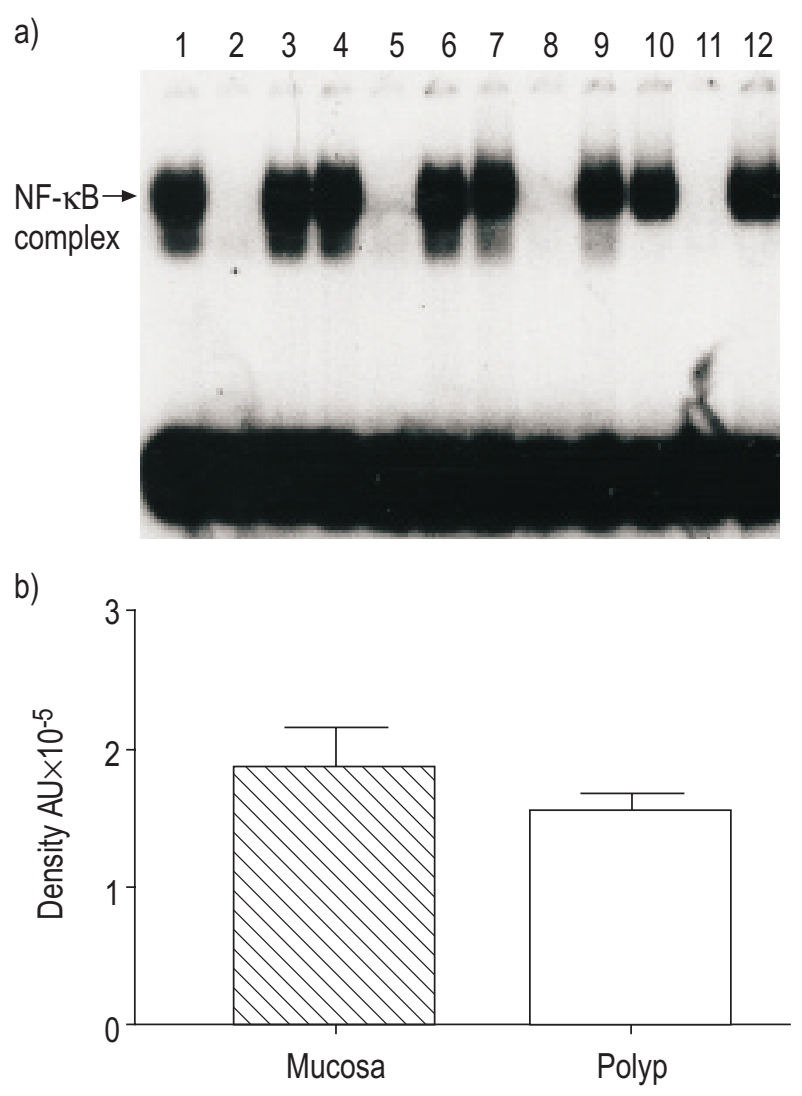

Fig. 1. - Representative electrophoretic mobility shift assay showing specific nuclear factor- $\kappa \mathrm{B}(\mathrm{NF}-\kappa \mathrm{B})$-binding activity in two nasal mucosa (lanes 1-6) and two nasal polyp tissues (lanes 7-12). Nuclear proteins (4 $\mu \mathrm{g})$ were incubated with 20,000 counts per minute of ${ }^{32} \mathrm{P}$-labelled consensus oligonucleotide for NF- $\mathrm{KB}$ binding. The specificity of the gel shift complexes was determined by preincubation in the presence of a 70 -fold excess of unlabelled NF- $\mathrm{KB}$ oligonucleotide (lanes 2, 5, 8, and 11) or excess noncompetitive unlabelled activator protein- 1 oligonucleotide (lanes 3, 6, 9 and 12). The radioactivity at the bottom of the gel is free probe. b) Densitometric scanning measurement (mean \pm SEM) of the NF- $\mathrm{BB}-$ retarded bands corresponding to healthy nasal mucosa $(n=13)$ and nasal polyp $(n=19)$ tissues. AU: arbitrary units.

\section{Inducible nitric oxide synthase immunoreactivity}

Since the expression of iNOS is normally associated with NF- $\mathrm{KB}$ activation, the presence of iNOS expression was examined, immunohistochemically, in the same healthy and inflamed nasal tissues exhibiting a high level of NF-kB DNA-binding activity. Both healthy nasal mucosa and nasal polyps showed prominent uniform iNOS staining of the whole epithelium (fig. 3a and c). The cytoplasm of all epithelial cells was labelled and no staining was seen in the nuclei. Additional staining was seen in the subepithelial glandular epithelium (fig. 4a), whereas vascular endothelium showed weak immunostaining (data not shown). Furthermore, a strong iNOS immunoreactivity was observed in the majority $(>90 \%)$ of the inflammatory cells characteristically infiltrating the nasal polyp submucosa layer (fig. 4b). Control sections incubated with IgG2a were not stained at all (fig. $3 b$ and d). These results indicate that the upper airway epithelium expresses the iNOS isoform independent of the inflammatory state of the tissue. 


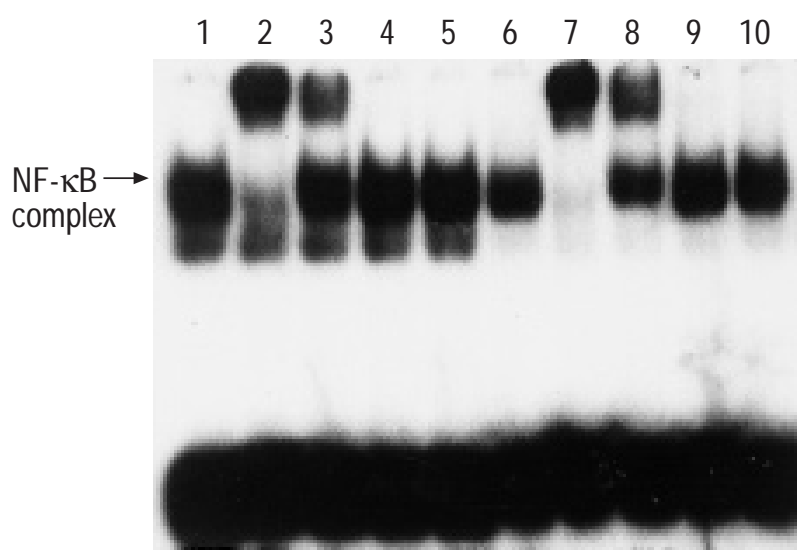

Fig. 2. - Identification of the nuclear factor- $\kappa \mathrm{B}(\mathrm{NF}-\kappa \mathrm{B}) / \mathrm{Rel}$ components present in nasal mucosa (lanes 1-5) and in nasal polyp (lanes 6-10) activated complexes. Supershift assays were performed with $4 \mu \mathrm{g}$ of nuclear extracts, which were incubated with 20,000 counts per minute of ${ }^{32} \mathrm{P}$-labelled consensus oligonucleotide for NF- $\mathrm{KB}$ binding in the $\mathrm{ab}-$ sence (lanes 1 and 6) or presence of antisera directed against p50 (lanes 2 and 7), p65 (lanes 3 and 8), c-Rel (lanes 4 and 9) or normal rabbit serum (lanes 5 and 10). The radioactivity at the bottom of the gel is free probe.

\section{Nuclear factor- $\kappa B$ activity in nasal epithelial cells}

To determine whether NF- $\mathrm{KB}$ is activated in nasal epithelial cells, EMSA was performed with nuclear proteins from cultured nasal mucosa and nasal polyp epithelial cells. Two shifted bands were detected in both types of cell (fig. $5 a$ ). These shifted bands were eliminated by the addition of a 70-fold excess of unlabelled NF- $\kappa$ B probe. The addition of an excess of the unrelated AP-1 oligonucleotide did not alter the shifted band. These data demonstrate the specificity of the NF- $\kappa \mathrm{B} / \mathrm{DNA}$ complexes and reveal that nasal epithelial cells obtained from nasal mucosa and nasal polyps contain constitutively activated $N F-\kappa B$ in the nuclei. NF- $\kappa \mathrm{B}$ band densitometry showed no difference between nasal epithelial cells obtained from healthy or inflamed tissues (fig. 5b). No shifted or a very faint band was detected in cultured fibroblasts obtained from these tissues (data not shown). Additionally, freshly isolated epithelial cells obtained by enzymatic dissociation were assayed by $\mathrm{NF}-\kappa \mathrm{B}$ activity and also contained similar levels of NF- $\kappa$ B-binding activity (data not shown). The supershift assays showed that p50 antisera completely

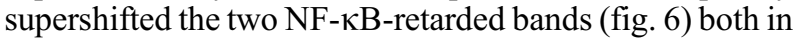
nasal mucosa and nasal polyp epithelial cells. In addition, the upper band was supershifted by p65 antisera and c-Rel resulted in a faint supershift. These data indicate that $\mathrm{p} 50$ is present in both bands and that the heterodimers p50/p65 and $\mathrm{p} 50 / \mathrm{c}-\mathrm{Rel}$ are present in the upper band. Whether the lower band is a p50 homodimer or a heterodimer of p50 with other subunits is yet to be elucidated.

\section{Discussion}

In this study, it was shown that NF- $\kappa \mathrm{B}$ is activated not only in nuclei from chronically inflamed nasal polyp tissue, as expected, but also, to the same extent, in nuclei from healthy nasal mucosa. In addition, prominent and uniform iNOS immunostaining was observed within the airway epithelium, independent of the inflammatory state of the tissue. Along with iNOS expression, activated NF- $\kappa \mathrm{B}$ was concomitantly also found in nonstimulated nasal epithelial cells isolated from both tissues and no difference in this was observed between nasal mucosa and nasal polyps. These data indicate that airway epithelial cells constitute a specific cell type containing both constitutively activated $\mathrm{NF}-\kappa \mathrm{B}$ and constitutively expressed iNOS.

The finding of constitutive NF- $\mathrm{B}$ DNA-binding activity in airway epithelium is in contrast to previous in vitro studies which failed to find activated NF- $\mathrm{KB}$ in the nuclei of primary or immortalized human respiratory epithelial cells. These studies showed that exposure to oxidants, irritants and inflammatory signals known to be active in chronic airway disease leads to NF- $\kappa \mathrm{B}$ activation and upregulation of some inducible genes [20-26], but, in the present work, NF- $\kappa \mathrm{B}$ is activated without apparent stimulation. These discrepancies could be due to differences between nasal epithelial cells, which constitute the first line of defence of the airways, and epithelial cells from the lower respiratory tract, such as tracheal epithelial cells [22], bronchial cells [24] or epithelial cell lines [20, 21, 23]. In addition, no differences could be found between the NF- $\kappa$ B activity in epithelial cells from nasal polyps and that in nasal mucosa, suggesting that constitutive NF$\kappa \mathrm{B}$ activity is important for normal epithelial cell function. Consistent with the present findings, other authors failed to detect differences between the NF- $\kappa$ B activity in bronchial epithelial cells from normal subjects and that in asthmatic patients [27]. In contrast, other studies have reported strong NF- $\mathrm{KB}$ DNA-binding activity in freshly isolated bronchial epithelial cells from asthmatic patients, which was absent in control cells [28].

Given the key role of NF- $\kappa \mathrm{B}$ in regulating genes involved in immune defence $[2,7]$ and taking into account the important function of the nasal mucosa and specifically of the epithelial cells in the defence of the lung against harmful agents, the present finding of constitutively activated NF- $\kappa B$ in airway epithelial cells, independent of the inflammatory state of the tissue, suggests that NF- $\kappa \mathrm{B}$ may play a role in airway defence; however, the physiological relevance of this finding is yet to be elucidated.

Identification of the specific NF- $\mathrm{KB} /$ Rel proteins that constitute the activated complexes present in the nuclei of normal and inflamed tissues, as well as in nasal epithelial cells, may be an important step in determining their function. The present results show that normal and inflamed tissues have the same pattern of subunit composition, in which p50 is the predominant subunit in the activated NF$\kappa \mathrm{B}$ complexes and p65 is present in lesser amounts in the whole tissue. These results indicate that nuclei from whole tissue probably predominantly contain the p50 homodimer and a lesser amount of the p50/p65 heterodimer, although the presence of other members of the Rel family, such as p52 or Rel B, cannot be excluded. The supershift assays, performed in nasal epithelial cells, demonstrate that the nuclei of both nasal mucosa and nasal polyp epithelial cells contain p50, p65 and c-Rel. The data indicate that the NF$\kappa \mathrm{B}$ constitutively activated complexes in nasal epithelial cells contain the p50 homodimer as well as the p50/p65 and the p50/c-Rel heterodimers. The presence of the c-Rel subunit only in epithelial cells and not in tissues may be related to the particular NF- $\kappa \mathrm{B} / \mathrm{Rel}$ composition of this cell type, which may be masked by other nonepithelial cells present in 

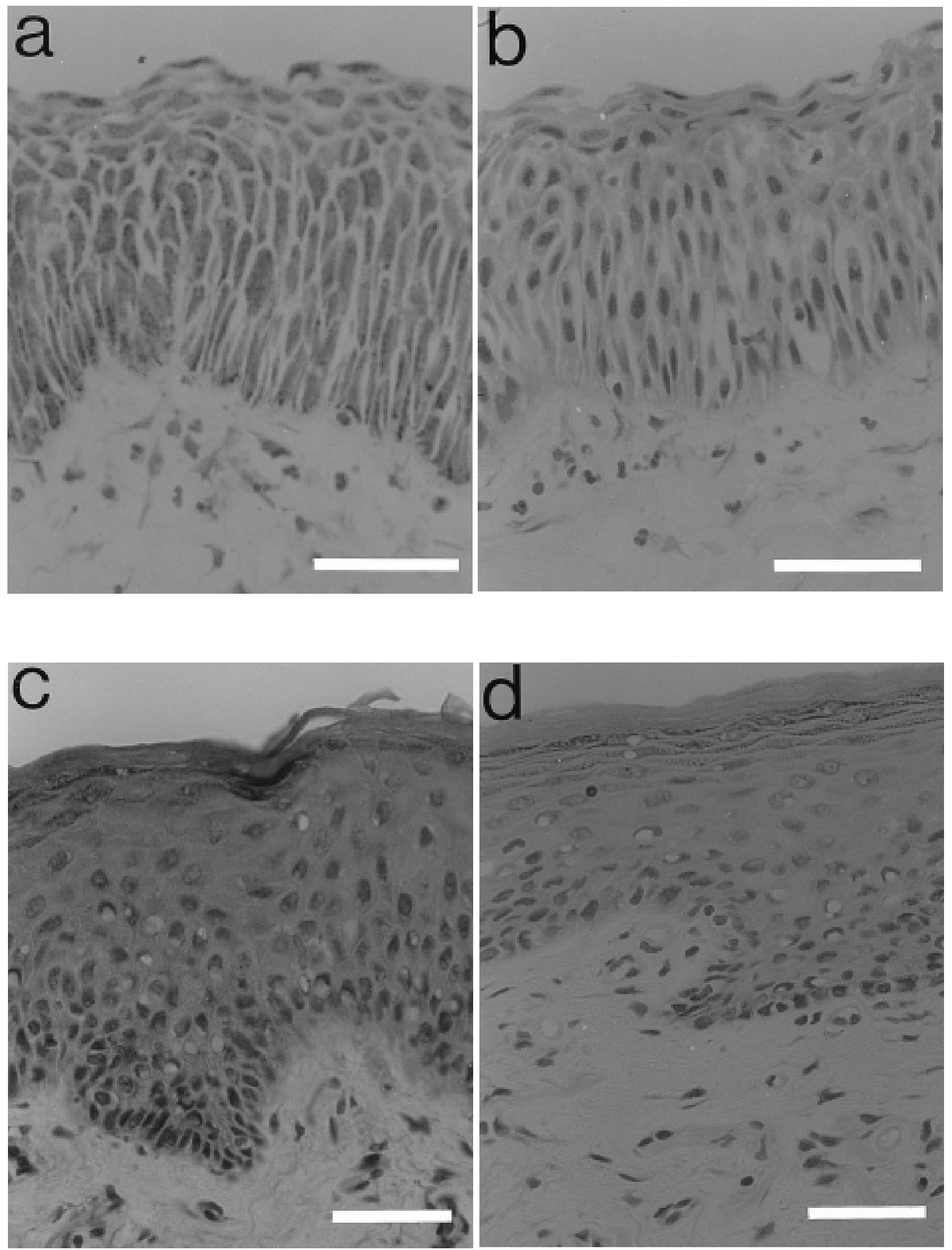

Fig. 3. - Immunohistochemical localization of inducible nitric oxidasynthase (iNOS) in: a, b) nasal polyp; and c, d) nasal mucosa sections: a) iNOS immunoperoxidase staining of the nasal polyp epithelium; b) staining control in a nasal polyp section in which the iNOS antibody was substituted by immunoglobulin (Ig)G2a; iNOS immunoperoxidase staining of the nasal mucosa epithelium; and d) staining control in a nasal mucosa section in which the iNOS antibody was substituted by IgG2a. (Internal scale bars=50 $\mu \mathrm{m}$.) 

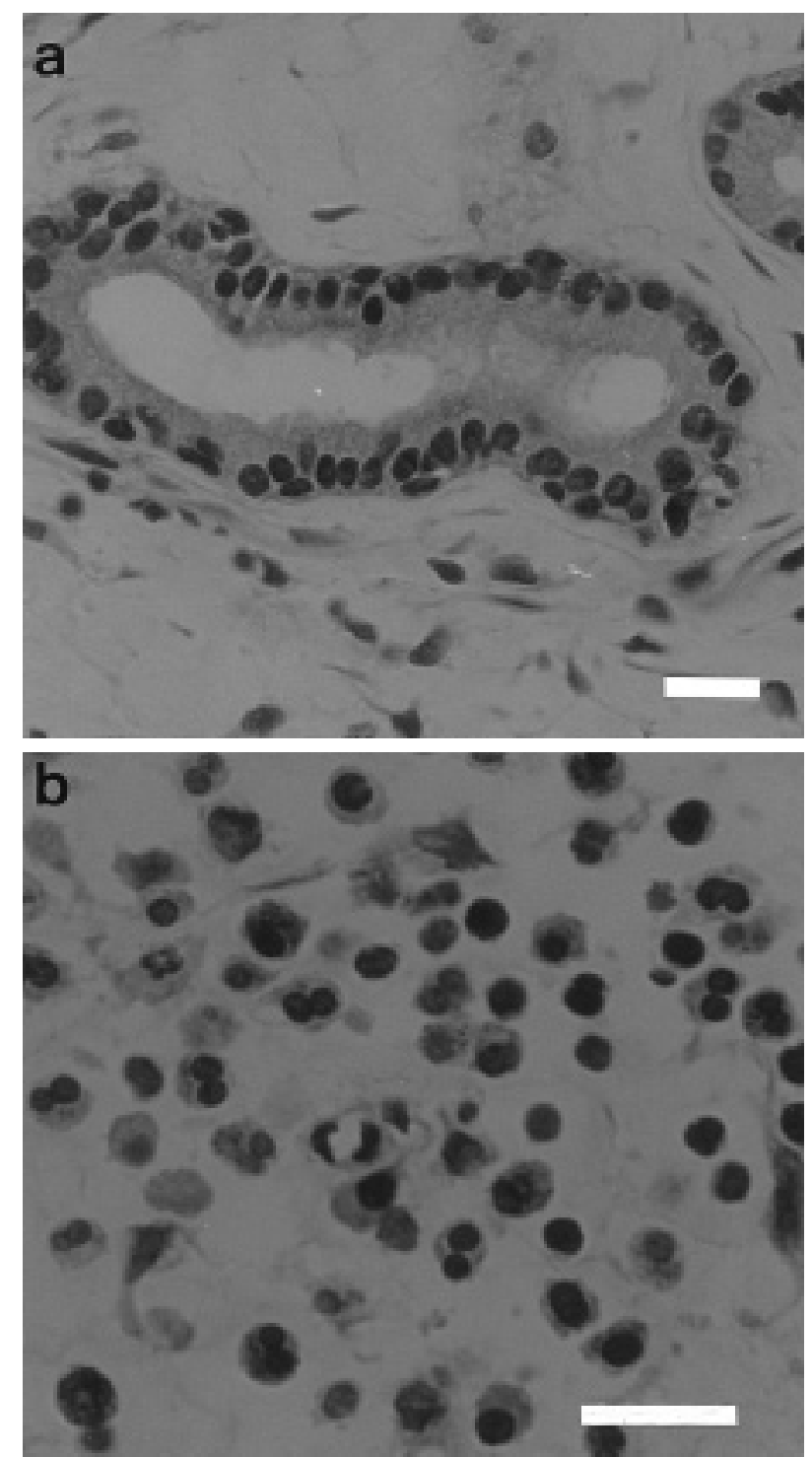

Fig. 4. - Immunohistochemical localization of inducible nitric oxide synthase (iNOS) in nasal polyp sections: a) iNOS immunoperoxidase staining in subepithelial glandular epithelium; and b) iNOS immunoperoxidase staining in inflammatory cells infiltrated in the nasal polyp submucosa. (Internal scale bars $=20 \mu \mathrm{m}$.)

whole tissue. Previous studies have shown that heterodimers of p50/p65 and p50/c-Rel bind a variety of $\mathrm{\kappa B}$ sites and cause transactivation by direct interaction with the basal transcription apparatus $[29,30]$, whereas the p50 homodimer lacks an identifiable transactivation domain and is unable, of itself, to significantly cause transactivation [5, 31].

The presence of constitutively activated NF- $\kappa \mathrm{B}$ complexes in the nuclei of nasal epithelial cells may be related to the regulation of genes whose expression is continuously required for the normal function of the upper airway system. Since, in the present work, iNOS immunoreactivity was found in the same tissues, both healthy and inflamed, that contain NF- $\kappa$ B activated complexes, it is tempting to suggest that iNOS may be one gene continuously induced by NF- $\kappa \mathrm{B}$ in the upper airway mucosa. Interestingly, the present results showed prominent iNOS immunoreactivity within the airway epithelium, both in nasal mucosa a) $\begin{array}{llllllllllll}1 & 2 & 3 & 4 & 5 & 6 & 7 & 8 & 9 & 10 & 11 & 12\end{array}$

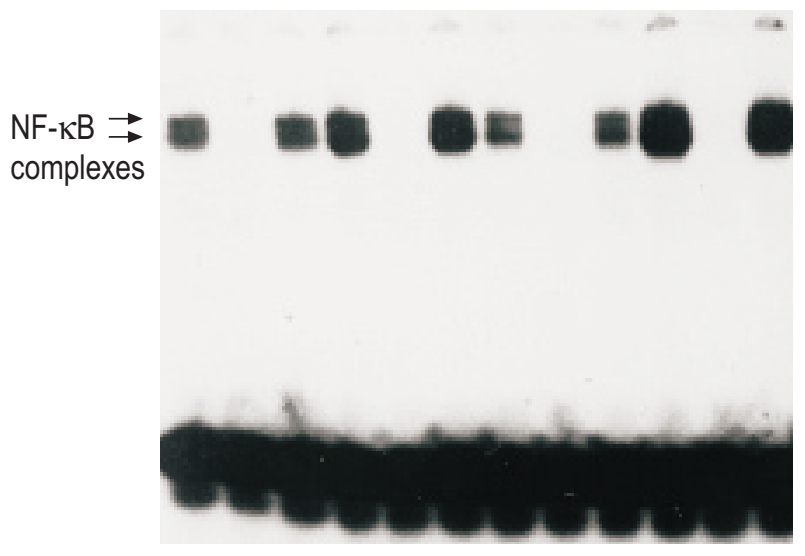

b)

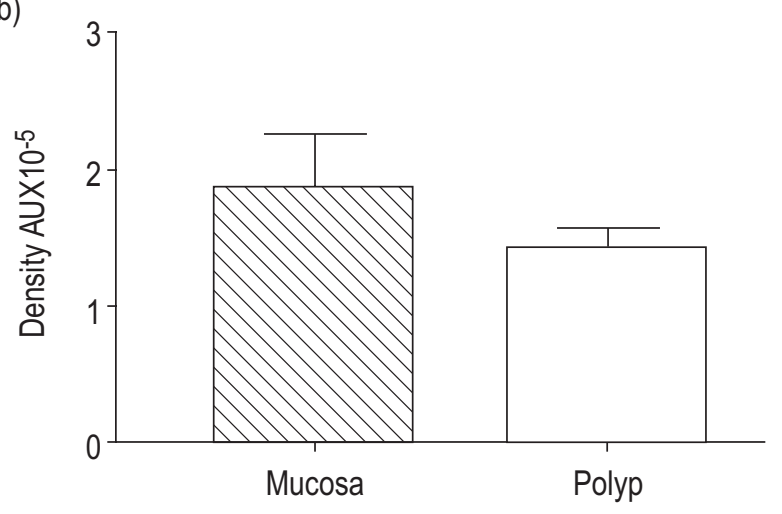

Fig. 5. - a) Representative electrophoretic mobility shift assay showing specific nuclear factor- $\kappa \mathrm{B}(\mathrm{NF}-\kappa \mathrm{B})$-binding activity in cultured epithelial cells obtained from two nasal mucosa (lanes 1-6) and two nasal polyp tissues (lanes 7-12). Nuclear proteins $(4 \mu \mathrm{g})$ were incubated with 20,000 counts per minute of ${ }^{32} \mathrm{P}$-labelled consensus oligonuclotide for NF- $\mathrm{\kappa B}$ binding. The specificity of the gel shift complexes was determined by preincubation in the presence of a 70 -fold excess of unlabelled NF- $\kappa \mathrm{B}$ oligonuclotide (lanes 2, 5,8 and 11) or excess noncompetitive unlabelled AP-1 oligonucleotide (lanes 3, 6, 9 and 12). The upper and lower band are indicated. The radioactivity at the bottom of the gel is free probe. $b$ ) Densitometric scanning measurement (mean \pm SEM) of the NF- $\kappa B-$ retarded bands corresponding to cultured epithelial cells obtained from nasal mucosa $(n=7)$ and nasal polyp $(n=13)$ tissues. AU: arbitrary units.

and chronically inflamed nasal polyps. In agreement with the present results, previous immunohistochemical studies have identified the presence of iNOS within airway epithelium, in normal nasal mucosa [32] as well as in human lung $[33,34]$. In contrast to the present study, which failed to show differences between inflammatory and normal airway epithelium, other authors have reported iNOS immunoreactivity in the bronchial epithelium of asthmatics but not in control patients [12]. These discrepancies may be explained by the differences between upper and lower airway function. The presence of iNOS in upper airway epithelium suggests that NO derived from iNOS may participate in the defence of the respiratory system through its effects on neurotransmission, immune defence, cytotoxicity, ciliary beat frequency and mucus secretion [35]. In terms of iNOS localization, the main difference between healthy and inflamed tissues was found at the level of the inflammatory cells present in nasal polyps, which were strongly positive for iNOS, as expected, since nasal polyp 


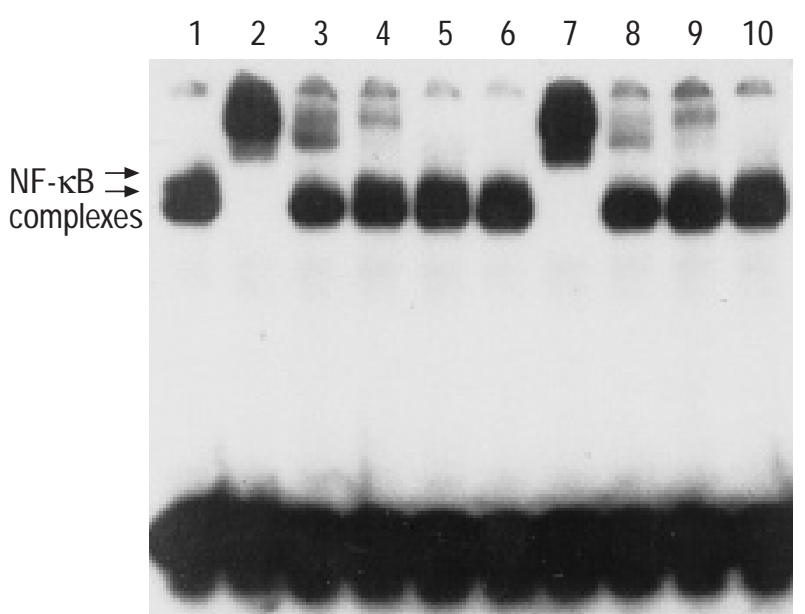

Fig. 6. - Identification of the nuclear factor- $\kappa \mathrm{B}(\mathrm{NF}-\kappa \mathrm{B}) / \mathrm{Rel}$ components present in nasal mucosa epithelial cell (lanes 1-5) and nasal polyp epithelial cell (lanes 6-10) activated complexes. Supershift assays were performed with $4 \mu \mathrm{g}$ of nuclear extracts, which were incubated with 20,000 counts per minute of ${ }^{32} \mathrm{P}$-labelled consensus oligonucleotide for NF- $\mathrm{BB}$ binding in the absence (lanes 1 and 6 ) or presence of antisera directed against p50 (lanes 2 and 7), p65 (lanes 3 and 8), c-Rel (lanes 4 and 9) or normal rabbit serum (lanes 5 and 10). The radioactivity at the bottom of the gel is free probe.

inflammatory cells produce a battery of cytokines, chemokines and growth factors [36], all of them well established stimulators of iNOS in a variety of cell types [37]. In agreement with this iNOS localization, another histochemical study has demonstrated the presence of iNOS in inflammatory cells in the nasal mucosa of patients with chronic rhinitis [32]. The present results would support the concept that infiltrating cells are important in regulating NO production within inflammatory airways.

In summary, inducible nitric oxide synthase expression in normal and inflammatory upper airway epithelium as well as constitutive nuclear factor- $\kappa \mathrm{B}$ activity in nasal epithelial cells from healthy nasal mucosa and nasal polyps have been demonstrated. The lack of differences, in both inducible nitric oxide synthase expression and the concurrent nuclear factor- $\kappa \mathrm{B}$ activity, when nasal epithelium from healthy and inflamed tissues is compared would suggest a physiological role for these factors in the airways. Further studies, based on the analysis of inducible nitric oxide synthase promoter/protein interactions, will allow it to be established whether or not constitutive nuclear factor- $\kappa \mathrm{B}$ activity is responsible for controlling the continuous inducible nitric oxide synthase expression in nasal epithelial cells.

Acknowledgements. The authors thank N. Rice (Frederick Cancer Research and Development Center, Frederick, MD, USA) for the generous gift of specific antisera to the family members of nuclear factor- $\kappa \mathrm{B}$.

\section{References}

1. Thompson $\mathrm{AB}$, Robbins RA, Romberger DJ, et al. Immunological functions of the pulmonary epithelium. Eur Respir J 1995; 8: 127-149.

2. Kopp BK, Ghosh S. NF- $\kappa$ B and Rel proteins in innate immunity. Adv Immunol 1995; 58: 1-27.

3. Lowenstein CJ, Alley EW, Raval P, et al. Macrophage nitric oxide synthase gene: two upstream regions mediate induction by interferon $\gamma$ and lipopolysacharide. Proc Natl Acad Sci USA 1993; 90: 9730-9734.

4. Xie Q-W, Kashivabara Y, Nathan C. Role of transcription factor NF- $\mathrm{\kappa B} /$ Rel in induction of nitric oxide synthase. $J$ Biol Chem 1994; 269: 4705-4708.

5. Baeuerle PA, Baltimore D. IкB: a specific inhibitor of the NF-кB transcription factor. Science 1988; 242: 540-546.

6. Lenardo MJ, Fan C-M, Maniatis T, Baltimore D. The involvement of NF- $\kappa \mathrm{B}$ in $\beta$-interferon gene regulation reveals its role as widely inducible mediator of signal transduction. Cell 1989; 57: 287-294.

7. Siebenlist U, Franzoso G, Brown K. Structure, regulation and function of NF-кB. Ann Rev Cell Biol 1994; 10: 405455 .

8. Kleinert H, Euchenhofer C, Ihrig-Biedert I, Förstermann U. In murine 3T3 fibroblasts, different second messenger pathways resulting in the induction of NO synthase II (iNOS) converge in the activation of transcription factor NF-кB. J Biol Chem 1996; 271: 6039-6044.

9. Kolyada AY, Savikosky N, Madias NE. Transcriptional regulation of the human iNOS gene in vascular-smoothmuscle cells and macrophages: evidence for tissue specificity. Biochem Biophys Res Commun 1996; 220: 600-605.

10. Kharitonov SA, Yates D, Robbins RA, Logan-Sinclair R, Shinebourne EA, Barnes PJ. Increased nitric oxide in exhaled air of asthmatic patients. Lancet 1994; 343: 133-135.

11. Persson MG, Zetterstrom O, Agrenius V, Ihre E, Gustafsson LE. Single-breath nitric oxide measurements in asthmatic patients and smokers. Lancet 1994; 343: 146-147.

12. Hamid Q, Springall DR, Riveros-Moreno V, et al. Induction of nitric oxide synthase in asthma. Lancet 1993; 342: $1510-1513$.

13. Ramis I, Lorente J, Roselló-Catafau J, Quesada P, Gelpí E, Bulbena O. Differential activity of nitric oxide synthase in human nasal mucosa and polyps. Eur Respir $J$ 1996; 9: 202-206.

14. Watkins DN, Lewis RH, Basclain KA, et al. Expression and localization of the inducible isoform of nitric oxide synthase in nasal polyp epithelium. Clin Exp Allergy 1998; 28: 211-219.

15. Guo FH, De Raeve HR, Rice TW, Stuehr DJ, Thunnissen FBJM, Erzurum SC. Continuous nitric oxide synthesis by inducible nitric oxide synthase in normal human airway epithelium in vivo. Proc Natl Acad Sci USA 1995; 92: 7809-7813.

16. Devalia JL, Sapsford RJ, Wells C, Richman P, Davies RJ. Culture and comparison of human bronchial and nasal epithelial cells in vitro. Respir Med 1990; 84: 303-312.

17. Sonnenberg JL, Macgregor-Leon PF, Curran T, Morgan JI. Dynamic alterations occur in the levels and composition of transcription factor AP-1 complexes after seizure. Neuron 1989; 3: 359-365.

18. Velasco M, Díaz-Guerra MJM, Díaz-Achirica P, Andreu D, Rivas L, Boscá L. Macrophage triggering with cecropin A and Melittin-derived peptides induces type II nitric oxide synthase expression. J Immunol 1997; 158: 4437-4443.

19. Bradford MM. A rapid and sensitive method for the quantitation of microgram quantities of protein utilizing the principle of protein-dye binding. Anal Biochem 1976; 72 : 248-254.

20. Adcock IM, Brown CR, Kwon O, Barnes PJ. Oxidative stress induces NF-KB DNA binding and inducible NOS mRNA in human epithelial cells. Biochem Biophys Res Commun 1994; 199: 1518-1524.

21. Jany B, Betz R, Schrech R. Activation of the transcription 
factor NF- $\mathrm{KB}$ in human tracheobronchial epithelial cells by inflammatory stimuli. Eur Respir J 1995; 8: 387-391.

22. Janssen YM, Barchowsky WA, Treadwell M, Driscoll $\mathrm{KE}$, Mossman BT. Asbestos induces nuclear factor- $\kappa \mathrm{B}$

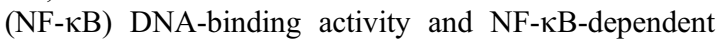
gene expression in tracheal epithelial cells. Proc Natl Acad Sci USA 1995; 92: 8458-8462.

23. Newton R, Adcock IM, Barnes PJ. Superinduction of NF$\kappa \mathrm{B}$ by actinomycin $\mathrm{D}$ and cycloheximide in epithelial cells. Biochem Biophys Res Commum 1996; 218: 518-52.

24. Manni A, Kleimberg J, Ackerman V, Bellini A, Patalano F, Mattoli S. Inducibility of RANTES mRNA by IL-1 $\beta$ in human bronchial epithelial cells is associated with increased NF-KB DNA binding activity. Biochem Biophys Res Commun 1996; 220: 120-124.

25. Asano K, Chee CBE, Gaston B, et al. Constitutive and inducible nitric oxide synthase gene expression, regulation, and activity in human lung epithelial cells. Proc Natl Acad Sci U S A 1994; 91: 10089-10093.

26. Robbins RA, Barnes PJ, Springall DR, et al. Expression of inducible nitric oxide in human lung epithelial cells. Biochem Biophys Res Commun 1994; 203: 209-218.

27. Guo FH, Dweik RA, Kaneko FT, Eissa NT, Erzurum SC. Molecular mechanisms of increased nitric oxide in asthma. Am J Respir Critical Care Med 1998; 157: A701.

28. Stacey MA, Sun G, Vassalli G, Marini M, Bellini A, Mattqli S. The allergen Der $\mathrm{pl}$ induces NF- $\kappa \mathrm{B}$ activation through interference with IкB $\alpha$ function in asthmatic bronchial epithelial cells. Biochem Biophys Res Commun 1997; 236: 522-526.
29. Schmitz ML, Baeuerle PA. The P65 subunit is responsible for the strong transcription activating potential of NF- $\mathrm{\kappa B}$. EMBO J 1991; 10: 3805-3817.

30. Inoue J-I, Kerr LD, Ransone LJ, Bengal E, Hunter T, Verma IM. c-Rel activates but v-rel suppresses transcription from $\kappa$ B sites. Proc Natl Acad Sci U S A 1991; 88: 3715-3719.

31. Baeuerle PA, Henkel T. Function and activation of NF- $\kappa B$ in the immune system. Annu Rev Immunol 1994; 12: 141179.

32. Furukawa KD, Harrison G, Saleh D, Shennib H, Chagnon FP, Giaid A. Expression of nitric oxide synthase in the human nasal mucosa. Am J Respir Crit Care Med 1996; 153 : 847-850.

33. Kobzik L, Bredt DS, Lowenstein CJ, et al. Nitric oxide synthase in human and rat lung: immunocytochemical and histochemical localization. Am JRespir Cell Mol Biol 1993; 9: 371-377.

34. Watkins DN, Peroni DJ, Basclain KA, Garlepp MJ, Thompson PJ. Expression and activity of nitric oxide synthases in human airway epithelium. Am J Respir Cell Mol Biol 1997; 16: 629-639.

35. Schmidt HHHW, Water U. NO at work. Cell 1994; 78: 919-925.

36. Bachert C, Wagenmann M, Rudack C, et al. The role of cytokines in infectious sinusitis and nasal polyposis. Allergy 1998; 53: 2-13.

37. Jorens PG, Vermeire PA, Herrnan AG. 1-arginine-dependent nitric oxide synthase: a new metabolic pathway in the lung and airways. Eur Respir J 1993; 6: 258-266. 